\title{
Relationship between marketing and community involvement: two significant factors for tourism strategies
}

\author{
S. F. Mostafavi Shirazi \& A. P. Mat Som \\ Universiti Sains Malaysia, Malaysia
}

\begin{abstract}
In considering the development of tourism destinations in a competitive market, a comprehensive viewpoint to tourism strategies is vital and valuable. A significant element of successful tourism strategies is the ability to recognize and concentrate a wide range of key factors and their interaction. Literature relating to relationship marketing and community involvement were reviewed and revealed that the concepts of relationship marketing, as well as communities' involvement, have been the subject of much research, but from a distinct perspective. Research pertaining to the linkage between relationship marketing and community involvement for strategies of tourism development is rather limited. This work is summarized in this article and the interrelation of the two most important issues for strategies of tourism development is discussed. Therefore, the purpose of this paper is to explore the role of relationship marketing and community involvement and their noticeable interaction for tourism strategies.
\end{abstract}

Keywords: relationship marketing, community involvement, loyalty, revisit, recommendation, tourism strategy.

\section{Introduction}

Global competitiveness in the tourism sector is the main theme in tourism strategies in the twenty-first century. The quality of basic elements in a tourist destination is an important aspect for achieving competitive advantages, but may not be enough. Nowadays, retaining tourists by developing relationships with them, as well as creating loyalty, are requisite to achieving competitive advantages. The purpose of this article is to discuss relationship marketing as a 
competitive strategy in tourism destinations, and to address issues that are relevant in community involvement as a key element to enabling relationship marketing strategies. The particular emphasis of this paper is upon the key role of the host community in creating a positive experience, as well as pleasant memories for their guests regarding relationship marketing strategies. Following an overall review of the concepts of 'relationship marketing' and 'community', an emphasis is placed upon loyalty in tourism destinations, as well as achieving competitive advantages.

\section{Relationship marketing}

The coming decade and a half will see major shifts in the leisure and tourism environment reflecting changing consumer values, political forces, environmental changes and the explosive growth of information and communication technology [13, p.1]. In these circumstances, reacting to the universal changes and achieving a competitive advantage requires a pragmatic and effective strategy. Relationship marketing (RM) describes a strategy for achieving a certain, obvious and sustainable competitive advantage [29].

The aim of RM is increasing customer satisfaction and retention through building long-term, trusting and win-win relationships [36]. Tourism has witnessed the introduction of many relationship marketing practices [15, p.645]. As a case in point, hotels frequently have guest programs [9, 27]. However, it has limited attention in destination literature [26]. RM can be regarded as an apt strategy and a coherent approach to building a continuing relationship among all key elements (e.g. stakeholders, host community, tourists) in the tourism destination to gain a competitive advantage.

The focal point of relationship marketing strategy, particularly in the tourism context, is on emergent long-term relationships and making appropriate corporate performance through customer loyalty and customer retention [8]. Loyalty is a primary goal of relationship marketing and sometimes is equated with the relationship marketing concept itself [3, p.13].

\subsection{Destination and loyalty}

Destination loyalty has not been comprehensively investigated [26]. On the basis of recent tourism destination studies, it has been widely acknowledged that the intention to revisit a destination and recommended the visit to others are both signs of loyalty $[2,4,5,24]$. Hence, repeat visitation and recommendation to other people as well as their benefits are now widely recognized by both academics and practitioners as an important issue in tourism strategies.

\subsubsection{Repeat visitation}

Intention to revisit a destination is considered an essential marketing goal, particularly in a competitive market, because it is assumed that repeat visitation has significant benefits. Repeat visits, at the point of economy, have been acknowledged as a significant event altogether and for individual attraction. As a 
matter of fact, many tourism destinations depend on repeat visitors to a great degree [10].

Reichheld makes the point to studies that have confirmed a 5\% increase in customer retention can make a profit increase of $25-95 \%$ across a variety of industries [28].

LeBoeuf argues that attracting new customer costs three to five times as much as retaining an old customer [22]. Rightly, in a competitive market, capturing new customers' attention from competitors is costly because a superior degree of service improvement is needed [1]. Most importantly, studies have also emphasized benefits of repeat visitors by influencing others through positive word-of-mouth (WOM) recommendation, as the other sign of loyalty.

\subsubsection{WOM recommendation}

Shoemaker and Lewis assert that loyal customers are more probable to be active as free word-of-mouth advertisers that bring networks of potential customers such as their friends and relatives to a product or service [32]. In the context of travel and tourism, recommendation by previous visits can be consider as the most reliable information source for potential tourists.

Recommendations to other people (WOM) are also one of the most often sought types of information for people interested in travelling [6, p.625]. The customers have not decided where they will go for a vacation and what they will do, looking for bright idea and recommendations [14]. The work by Shanka et al., on the methods of destination selection, confirms the positive affect of WOM. They found that the largest part of travel decisions of Western Australia were base on WOM information [31]. WOM recommendation may be a more influential and cheaper than any other marketing strategies [11].

\section{Community involvement in tourism}

Beeton asserts "community" is a dialogic concept, interpreted within a particular context. In this sense, community describes the inhabitants of a place, an ethnic grouping, and persons who share a sense of belonging, common interests, values, or aspirations [12, p.1097]. Haywood believes that the community assets (landscape and heritage), public goods (parks, institutions and museums), and hospitality (government promotion and welcoming smile) are provided by a destination community, that are the backbone of the tourism industry [19]. In this regard, many studies have examined the community involvement, in tourism destinations, from different perspectives [20, 21, 25].

This article considers community involvement from two important aspects.

1) Involvement in planning

2) Creating a pleasant remembrance

\subsection{Involvement in planning}

In tourism literature, the benefits of including community involvement in tourism planning and management are highlighted by many scholars [17, 23, 34]. Perhaps, community involvement can be seen as important due to the local 
knowledge that exists within communities which can be of major importance in tourism development [30, p.137]. A recent study by Nyaupane et al. [25, p.1374] indicates that members of a host community should be involved in tourism planning because they: (a) have an historical understanding of how the region adapts to change; (b) will be the most closely affected by tourism; and (c) will be expected to become integral part of the tourism product [33,34]. Residents should also be involved in decisions regarding the development of tourism in their area and work with other stakeholders to enhance opportunities within the tourism sector [14, p.115].

From the other perspective, involvement of local communities for sustaining the product is mentioned as a key factor since 1980s [18]. In terms of this discussion, the involvement of local communities in tourism planning is vital and remarkable for achieving competitive advantages. Existing or new support suppliers should liaise closely with local communities to fully understand opportunities, obstacles and feasible approaches, and they should then design creative policies to facilitate these processes [14, p. 92]. Accordingly, community participation as a key component should be strongly considered within tourism strategies.

\subsection{Creating a pleasant memory}

Hospitality is a crucial factor in the tourism industry. People who travel for pleasure and relaxation place a great value on the friendly and generous behaviour they receive from the host community. As Young rightly points out, people in marketing recognize very well that of all the factors which make pleasure and delight in travel, there is none more important than the way travellers are considered and treated by inhabitants in tourist destination [37]. By the same token, Crick warned that when a local community in the Caribbean show signs of unfriendly or aggressive feeling towards tourists, the effect is harmful WOM and to be expected to result in a decline in the industry [7].

The participation of the local community is important in ensuring that visitors get an unforgettable, pleasant tourist experience, while at the same time enabling the community to benefits from their visits [30, p.137]. Cleary, the customer will recall their journey and will assess whether it was good or bad. If the experience was good, then the customer may recommend to others, or return themselves [14, p.19].

Host communities' behaviour toward tourists is extremely important to influence their satisfactory experience of travel and loyalty. Importantly, they play a key role in creating a good remembrance for tourist via a friendly behaviour to meet customers' needs and wants, in every stage of journey from arrival at the destination to departure.

\section{Comprehensive perspective}

Tourism strategy is often submerged in discussion of destination management and marketing [35, p.252]. It is acknowledged by many scholars that astonishing 
global changes related technology, economy, demography and etc., particularly in $21^{\text {th }}$ century, have great influences in tourist's values and needs as well as destinations. Dwyer et al. emphasized the increasing competition in the tourism and hospitality industries - between destinations worldwide (between established markets and from new markets), between destinations domestically, and between firms within a destination [13, p.1]. In this regard, achieving competitive advantages to maintain customers and create long-term relationship requires a proper strategy.

According to Fyall et al. relationship marketing arguably provides a potential and considerable situation to succeed in reaching competitive advantage [15].

The most important theme that relationship marketing strategy operates, in competitive destination, is building long-term relationship with tourists and creating loyalty. In this approach, interaction and contribution of each parts of destination that make it up, is vital.

It strongly emphasized that don't just consider two-party relationship between customer and supplier; consider all stakeholders in a network [16, p.41]. Therefore, community involvement is a necessary factor for operating relationship marketing strategy in tourism industry. The fundamental reason for this claim related to the responsibility of local communities as host community for encouraging tourists to revisit and WOM referrals. Clearly, not only employees who offer service/products to tourist but also all of the destination communities are responsible for operating these communications. Residents of a destination can build a base for memorable relationship and affect tourist memories, even by offering a cheery remark and welcome.

\section{Conclusion}

Taking the above discussion into account, for achieving competitive advantages, relationship marketing and community involvement are significant factors that should be considered in tourism strategies.

Cooperative host community efforts to generate memorable visit would be thoughtful action and significant for operating relationship marketing strategy.

The overall experience of the tourist at the destination is often affected by the attitudes of local residents towards tourism and tourist [14, p.114]. Consequently, host community's interactions with tourists are an important part of their experience with the destination that should be firmly deliberated by tourism authority.

Creating a feeling of participation and responsibility, with raising awareness of advantages of involvement, encouraging to share and exchange the information and knowledge for effective planning, is strongly recommended by researchers and practitioners. Regarding relationship marketing strategy to achieve competitive advantages, it is important to understand the key role of host community in generating a pleasant experience and unforgettable remembrance for revisit and positive recommendation. 


\section{References}

[1] Anderson, W. E. \& Sullivan, W. M., The antecedents and consequences of Customer satisfaction for firms. Marketing Science, 12, pp. 125-143, 1993.

[2] Bigne, J. E., Sa`nchez, M. I., \& Sa`nchez, J., Tourist image, evaluation variables and after purchase behaviour: Inter- relationship. Tourism Management, 22(6), pp.607-616, 2001.

[3] Boonajsevee, B., Relationship Marketing: Loyalty Intentions in New Era of Thia Bank Marketing, Dissertation, Nova Southern University, 2005.

[4] Cai, L. A., Wu, B. \& Bai, B., Destination image and loyalty. Cognizant Communication Corporation, 7, PP. 153-162, 2003.

[5] Chen, J. \& Gursoy, D., An investigation of tourists' destination loyalty and Preferences. International Journal of Contemporary hospitality Management, 13, pp. 79-86, 2001.

[6] Chi, C. G. \& Qu, H., Examining the structural relationships of destination image, tourist satisfaction and destination loyalty: An integrated approach. Tourism Management, 29(4), pp. 624-636, 2008.

[7] Crick, A. P. International marketing of attitudes in Caribbean tourism. International of Contemporary Hospitality Management, 15 (3), PP. 161166, 2003.

[8] CRM Today, www.crm2day.com. Accessed website on January 25, 2007.

[9] Danaher, P. \& Mattsson, J., Cumulative Encounter Satisfaction in the Hotel Conference Process. International Journal of Service Industry Management, 5(4), pp. 68-82, 1994.

[10] Darnell, A. C. \& Johnson, P. S., Repeat visits to attractions: A preliminary economic analysis. Tourism Management, 22(2), pp.119-126, 2001.

[11] Dharmaratne, G.S., Sang, F.Y. \& Wailing, L.J., Tourism potentials for financing protected areas. Annals of Tourism Research, 27(3), pp. 590-610, 2000.

[12] Dredge, D., Community Development through Tourism. Annals of Tourism Research, 34(4), pp. 1097-1099, 2007.

[13] Dwyer, L., Edwards, D., Mistilis, N., Roman, C. \& Scott, N., Destination and enterprise management for a tourism future. Tourism Management, 30(1), pp.63-74, 2009.

[14] Fabricius, M., Carter, R. \& Standford, D., A Practical Guide to Tourism Destination Management, World Tourism Organization, Madrid, 2007.

[15] Fyall, A., Callod, C. \& Edwards, B., Relationship Marketing: the challenge for destinations. Annals of Tourism Research, 30(3), pp. 644-659, 2003.

[16] Gummesson, E., Life Is a Network of Relationships- and so Is Tourism, ppt. in ATMC, Universitat de Valencia, 2007.

[17] Gunn, C. A., Tourism planning ( $\left.2^{\text {nd }} e d.\right)$, New York: Taylor \& Francis, 1988.

[18] Hardy, A., Beeton, R. \& Pearson, L., Sustainable tourism: an overview of the concept and its position in relation to conceptualisations of tourism. Journal of Sustainable Tourism, 10(6), pp. 475-496, 2002.

[19] Haywood, K. M., Responsible and responsive tourism planning in the community. Tourism Management, 9(2), pp.105-118, 1988. 
[20] Horn, C. \& Simmons, D., Community adaption to tourism: comparisons between Rotorua and Kaikoura, New Zealand. Tourism Management, 23(2), pp.133-143, 2002.

[21] Lai, K., Li, Y. \& Feng, X., Gap between planning and implementation: A case of China. Tourism Management, 27(6), pp. 1171-1180, 2006.

[22] LeBoeuf, M., How to Win Customers and Keep Them for Life, Berkley Books, New York, 1987.

[23] Murphy, P. E., Tourism: A community approach. New York: Routledge, 1985.

[24] Niininen, O., Szivas, E. \& Riley, M., Destination loyalty and repeat behaviour: An application of optimum stimulation measurement. International Journal of Tourism Research, 6(6), pp. 439-447, 2004.

[25] Nyaupane, G. P., Morais, D. B. \& Dowler, L., The role of community involvement and number/type of visitors on tourism impacts: A controlled comparison of Annapurna, Nepal and Northwest Yunnan, China. Tourism Management, 27(6), pp. 1373-1385, 2006.

[26] Oppermann, M., Tourism destination Loyalty. Journal of Travel Research, 39(1), pp. 78-84, 2000.

[27] Palmer, A., Beattie, U. \& Beggs, R. A Structural Analysis of Hotel Sector Loyalty Programs. International Journal of Contemporary Hospitality Management, 12, pp. 54-60, 2000.

[28] Reichheld, F. F., The loyalty effect, Boston, MA: Harvard Business School Press, 1996.

[29] Roberts, K. Varki, S. \& Brodie, R., Measuring the quality of relationships in consumer services: An empirical study. European Journal of Marketing, 37(1/2), pp. 169-196, 2003.

[30] Sebele, L., Community-based tourism ventures, benefits and challenges: Khama Rhino Sanctuary Trust, Central District, Botswana. Tourism Management, 31(1), pp. 136-146, 2010.

[31] Shanka, T., Ali-Knight, J. \& Pope, J., Intrastate travel experiences of International students and their perceptions of Western Australia as a tourist destination. Tourism and Hospitality Research, 3(3), pp. 245-256, 2002.

[32] Shoemaker, S. \& Lewis, R. C., Customer loyalty: The future of hospitality Marketing. International Journal of Hospitality Management, 18, PP. 345$370,1999$.

[33] Scheyvens, R., Ecotourism and the empowerment of local communities. Tourism Management, 20(2), pp. 245-249, 1999.

[34] Simmons, D. G., Community participation in tourism planning. Tourism Management, 15(2), pp. 245-249, 1994.

[35] Stokes, R., Tourism strategy making: Insights to the events tourism domain. Tourism Management, 29(2), pp. 252-262, 2008.

[36] Varvra, Terry G., after marketing: How to keep Customers for life Through Relationship Marketing, McGraw Hill Companies, 1995.

[37] Young, G., The Role of Community Participation in tourism Planning, MSc Dissertation. University of Strathclyde, 1992. 